\title{
Aloe Vera Peel Extract Administration Increased Antioxidant Enzyme Levels of Serum and Seminal Plasma in Type 2 Diabetic Rats
}

\author{
Wulan Christijanti ${ }^{1, *}$, Achmad Zulfa Juniarto ${ }^{2}$, Lisyani B. Suromo ${ }^{3}$
}

Wulan Christijanti ${ }^{1, *}$, Achmad Zulfa Juniarto ${ }^{2}$, Lisyani B. Suromo ${ }^{3}$

'Doctoral Program of Medical/Health Science, Faculty of Medicine, Diponegoro University Semarang, INDONESIA.

${ }^{2}$ Division of Biology and Biochemistry, Faculty of Medicine, Diponegoro University Semarang, INDONESIA.

${ }^{3}$ Division of Clinical Pathology, Faculty of Medicine, Diponegoro University Semarang, INDONESIA

\section{Correspondence}

drh. Wulan Christijanti, M.Si.

Program Studi Doktor IImu Kedokteran/ Kesehatan, Fakultas Kedokteran,

Universitas Diponegoro Semarang, Jalan

Imam Bardjo, S.H. No. 5 Lt. 5 Semarang,

Central Java, 50241, INDONESIA.

E-mail: wchristijanti@gmail.com

History

- Submission Date: 12-05-2019;

- Review completed: 12-06-2019;

- Accepted Date: 12-06-2019

DOI : 10.5530/pj.2019.11.152

Article Available online

http://www.phcogj.com/v11/i5

\section{Copyright}

(C) 2019 Phcogj.Com. This is an openaccess article distributed under the terms of the Creative Commons Attribution 4.0 International license.

\begin{abstract}
Background: Diabetes mellitus (DM) is considered as a complex metabolic disorder characterized by hyperglycemia. Aim: The present study aimed to evaluate the effect of Aloe vera peel extract on the antioxidant levels of serum and seminal plasma of type 2 diabetic rats. Materials and Methods: Male Wistar rat was injected by $65 \mathrm{mg} / \mathrm{kg}$ streptozotocin (STZ) combined with $230 \mathrm{mg} / \mathrm{kg}$ of Nicotinamide acid (NA) intraperitoneally. The rats were declared to have diabetic with fasting blood glucose level $>200 \mathrm{mg} / \mathrm{dl} 72$ hours after induction. Diabetic rat samples were divided into four groups, control group (diabetes without treatment) and three groups were treated by Aloe vera peel extracts orally: $100 \mathrm{mg}$ (P.1), $200 \mathrm{mg}$ (P.2), and $400 \mathrm{mg} / \mathrm{kg}$ body weight (P.3), respectively. Antioxidant levels of serum and seminal plasma, including superoxide dismutase (SOD), catalase (CAT) and glutathione (GSH) were examined after 28 days of treatment. Results: The levels of SOD, CAT, and GSH in the group receiving Aloe vera peel extract were statistically significant $(p<0.05)$ higher than the control. There were also significant differences between the dose variations group. Conclusion: Aloe vera peel extract can significantly increase antioxidant levels in serum and seminal plasma of type 2 diabetic mice.

Key words: Aloe vera peel extract, Antioxidants, Diabetes, Seminal Plasma, Serum.
\end{abstract}

\section{INTRODUCTION}

Diabetes mellitus (DM) is a heterogeneous and complex metabolic disorder characterized by high blood glucose levels (hyperglycemia). Insufficient or ineffective insulin contributes to the etiology of diabetes. Type 1 diabetes is an autoimmune disease that causes pancreas $\beta$ cell damage resulting in insulin deficiency, whereas type 2 diabetes develops due to inefficient use of insulin or insufficient insulin production. ${ }^{1}$ Prevalence of diabetes in the world in the adult age range $20-79$ year by $6.4 \%$ affecting 285 million (2010). It will increase to $7.7 \%$ and 439 million people by $2030 .^{2}$ In addition, between 2010 and 2030, there will be a $69 \%$ increase in developing countries and $20 \%$ in developed countries. ${ }^{3}$

Hyperglycaemia in diabetes leads to oxidative stress conditions with increased free radical formation derived from non-enzymatic protein glycation, glucose oxidation, and increased lipid peroxidation. This results can damage the enzymes, cellular machinery, and increased insulin resistance; therefore, the oxidative stress becomes an essential factor in the pathophysiology of diabetes complications. ${ }^{4,5}$ In addition, oxidative stress in diabetes is also caused by decreased antioxidant mechanisms with reduced catalase production (CAT), superoxide dismutase (SOD) and glutathione peroxidase (GSH) ${ }^{6}$ The mechanisms of antioxidant protection in helping diabetes treatment and its complications have been demonstrated in experimental, clinical, and epidemiological studies. ${ }^{7}$ Antioxidants can inhibit the activity of free radicals through several ways such as acting as an enzyme, the ability to bind metals that stimulate the production of free radicals and act as free radical scavengers. ${ }^{8}$ Various types of antioxidants, especially from natural sources such as enzymes (SOD, CAT, and GSH), tocopherol, carotenoids, ascorbic acid, polyphenols can inhibit cell damage from free radicals. ${ }^{9}$

In recent decades, WHO has supported traditional treatment programs with medicinal plants. ${ }^{10}$ Medicinal plants are plants that in one or more parts such as leaves, roots, rhizomes, stems, bark, flowers, fruits, grains contain substances that can be used for therapeutic purposes. ${ }^{11}$ Research on plants containing glycosides, alkaloids, terpenoids, anthocyanins, tocopherols, flavonoids, carotenoids, polyphenols, peptidoglycan, steroids, coumarin and other constituents are often involved as an antidiabetic activity. ${ }^{12}$

The gel and peel of Aloe vera are common in use as alternative medicines. There is the fact that Aloe vera peel has a higher content of phenol and flavonoid compounds than in the gel ${ }^{13}$ and it is widely employed in the study of antioxidant activity. ${ }^{14,15}$ Moreover, Aloe vera peel extract has been examined for its antimicrobial effect against Staphylococcus aureus, Bacillus spp., Enterococcus spp., and Aspergillus niger which was characterized by a significantly reduced number of bacterial and fungal colonies after treatment using peel extract. ${ }^{16,17}$ Aloe vera peel 
also has strong scavenging activity against radical superoxide and is moderate for lipid peroxidation. ${ }^{18}$ Other researchers state that peel extracts can significantly reduce serum 8-oxo-dG levels compared to the gel..$^{19}$

\section{MATERIALS AND METHODS}

\section{Animal samples and experimental design}

An experimental study with post test only control group design was employed. Thirty-two Wistar rats weighing 175 - $200 \mathrm{~g}$ were acclimated for one week before treatment. Rats were placed in individual cages with a standard feed of pellets and ad libitum drinking. They were maintained indoors with temperatures at $\pm 24{ }^{\circ} \mathrm{C}$, humidity and light-dark cycles of $12 \mathrm{~h}: 12 \mathrm{~h}$ by laboratory protocol of Food and Nutrition, Inter-University Food and Nutrition Studies Center, Gadjah Mada University, Yogyakarta. The Commission of Health Research Ethics Faculty of Medicine Diponegoro University/RSUP dr. Kariadi Semarang has approved this research.

\section{Chemicals}

Streptozotocin (No: 32238-91) and nicotinamide acid (No: 24303-84) were obtained from Nacalai Tesque, Inc. Kits from bioVision Inc., USA were used for examining the serum and seminal plasma antioxidant; i.e., superoxide dismutase (Catalog \#K335-100), catalase (Catalog \# K773-100) and glutathione (Catalog \# K264-100).

\section{Extraction of Aloe vera}

Aloe vera plants were obtained from Sleman, Special Region of Yogyakarta Province, Indonesia. The plants were subsequently identified in the Laboratory of Plant Taxonomy, Department of Biology, Faculty of Mathematics and Natural Sciences, Universitas Negeri Semarang (No. 800/UN/37.1.4.5/LT/2017). Aloe vera leaf peel was cut into small pieces $\pm 2 \mathrm{~cm}$. It was dried in a cabinet dryer at $40{ }^{\circ} \mathrm{C}$ and mashed into flour. The flour was dissolved in $70 \%$ ethanol with a ratio of 1:10, macerated for $48 \mathrm{~h}$ to get the macerate which was further concentrated with the rotary evaporator to obtain the viscous extract.

\section{Induction of type 2 diabetes mellitus and treatment}

Thirty-two rats were injected with a single dose of streptozotocin at $65 \mathrm{mg} / \mathrm{kg}$ and nicotinamide acid at $230 \mathrm{mg} / \mathrm{kg}$ body weight intraperitoneally. Diabetic rats were characterized by blood glucose levels of $\geq 200 \mathrm{mg} / \mathrm{dl}$ at $72 \mathrm{~h}$ after induction..$^{20}$ Then, it was divided into 4 groups with 8 rats on each group, i.e., the first group is control group (C) that treated using placebo, second group was received $100 \mathrm{mg} / \mathrm{kg}$ (P.1), then for third $200 \mathrm{mg} / \mathrm{kg}$ (P.2) and fourth group were received $400 \mathrm{mg} / \mathrm{kg}$ of Aloe vera peel extract (P.3). Aloe vera leaf peel extract was given for 28 days.

At the end of the study, blood was taken from an orbital vein with microhematocrit and collected in the microtubes with EDTA as an anticoagulant. Microtubes were centrifuged at $4000 \mathrm{rpm}$ for 15 min to get the serum. Rats were decapitated and dissected in the abdominal section. Then, testes and its ducts were taken. Next, the caudal epididymis section was cut into pieces and mixed with $2 \mathrm{ml}$ PBS (phosphate buffer saline) solution. Homogenate was centrifuged at $4000 \mathrm{rpm}$ for $15 \mathrm{~min}$ to obtain the supernatant used for examination of superoxide dismutase, catalase, and glutathione. ${ }^{21}$ Superoxide dismutase (SOD) serum and seminal plasma were measured using the xanthine oxidase activity. ${ }^{22}$ Catalase (CAT) was measured based on the reduction of the hydrogen peroxide bond $\left(\mathrm{H}_{2} \mathrm{O}_{2}\right) .{ }^{23}$ Glutathione ( $\mathrm{GSH}$ ) was examined based on the 5,5-dithiobis (2-nitrobenzoic acid) (DTNB) reaction. $^{24}$

\section{Data analysis}

Data were presented as the mean \pm standard deviation (SD). The significant difference between the control group and treatment groups was analyzed statistically by one-way ANOVA followed by LSD (Least Significance Different) test. The result is significant with the p-value at $<0.05$.

\section{RESULTS}

The results of the antioxidant of the serum are presented in Table 1. The mean SOD of the control group $(21.81 \pm 5.97)$ showed a significant difference $(p<0.05)$ compared with P.1 (39.21 \pm 7.49$)$, P.2 $(52.20 \pm$ $6.28)$ and P.3 (59.56 \pm 5.34$)$. P.1 was significantly different $(p<0.05)$ with P.2 and P.3; P.2 was also significantly different from P.3. Aloe vera peel extract of each dose 100, 200 and $400 \mathrm{mg} / \mathrm{kg}$ gave a significant difference in the levels of CAT and GSH P.1 $(2.48 \pm 0.07$ and $46.01 \pm$ 3.27), P.2 ( $5.07 \pm 0.12$ and $66.17 \pm 2.97)$ and P.3 (5.65 \pm 0.29 and 76.01 $\pm 2.06)$ compared to the control group $(1.89 \pm 0.15$ and $27,88 \pm 3.26)$. Catalase and GSH between treatment groups also showed a significant difference $(p<0.05)$.

Aloe vera leaf peel extract was able to significantly increased SOD, CAT, and GSH of the serum. Figure 1 shows that the control group is lower for SOD, CAT, and GSH than the treatment group and will increase consecutively according to the dose of Aloe vera peel extract given at 100,200 and $400 \mathrm{mg} / \mathrm{kg}$.

The superoxide dismutase of seminal plasma in the control group $(14.22 \pm 7.09)$ was significantly lower with P.1 $(27.94 \pm 6.93)$, P.2 (46.32 \pm 5.64$)$ and P.3 (49.02 \pm 6.79$)$, as well as P.1, compared to P.2 and P.3 group; while P.2 was no different from P.3. The control group CAT levels $(1.83 \pm 0.15)$ showed significant different $(p<0.05)$ with the treatment group, also for P.1 $(2.40 \pm 0.09)$, P.2 (5.04 \pm 0.09$)$ and P.3 (5.56 \pm 0.19$)$, which was significantly different one with others. Glutathione of seminal plasma of control group (26.91 \pm 2.96$)$, P.1 (43.89 \pm 4.09), P.2 (63.28 \pm 3.85$)$ and P.3 (73.02 \pm 2.33$)$ showed significant differences in each group (Table 2).

The superoxide dismutase level of seminal plasma (14.22 U/ml), CAT $(1.83 \mathrm{nmol} / \mathrm{ml})$ and GSH $(26.91 \mu \mathrm{g} / \mathrm{ml})$ were the lowest control group which would then increased according to the dose of Aloe vera extract given successively P.1 $(27.94,2.40,43.89)$, P.2 $(46.32 ; 5.04 ; 63.28)$ and P.3 (49.02; 5.56; 73; 02) (Figure 2).

Table 1: Superoxide dismutase, catalase and glutathione of type 2 diabetic rat serum on control and treatment group of Aloe vera peel extract.

\begin{tabular}{cccc}
\hline Group & $\begin{array}{c}\text { Superoxide dismutase } \\
(\text { SOD) }(\mathrm{U} / \mathrm{ml})\end{array}$ & Catalase $(\mathrm{CAT})(\mathrm{nmol} / \mathrm{ml})$ & $\begin{array}{c}\text { Gluthatione }(\mathrm{GSH}) \\
(\mu \mathrm{g} / \mathrm{ml})\end{array}$ \\
\hline $\mathrm{DM}+$ Distilled water & $21.81 \pm 5.97$ & $1.89 \pm 0.15$ & $27.88 \pm 3.26$ \\
$\mathrm{DM}+100 \mathrm{mg} / \mathrm{kg} /$ day & $39.21 \pm 7.49^{* *}$ & $2.48 \pm 0.07^{* *}$ & $46.01 \pm 3.27^{* \#}$ \\
$\mathrm{DM}+200 \mathrm{mg} / \mathrm{kg} /$ day & $52.20 \pm 6.28^{* *}$ & $5.07 \pm 0.12^{* *}$ & $66.17 \pm 2.97^{* *}$ \\
$\mathrm{DM}+400 \mathrm{mg} / \mathrm{kg} /$ day & $59.56 \pm 5.34^{* *}$ & $5.65 \pm 0.29^{* *}$ & $76.01 \pm 2.06^{* *}$ \\
\hline
\end{tabular}

Data is presented as mean $\pm \mathrm{Sd}$. ${ }^{*} p<0.05$ compared to control ${ }^{*} p<0.05$ between treatments 


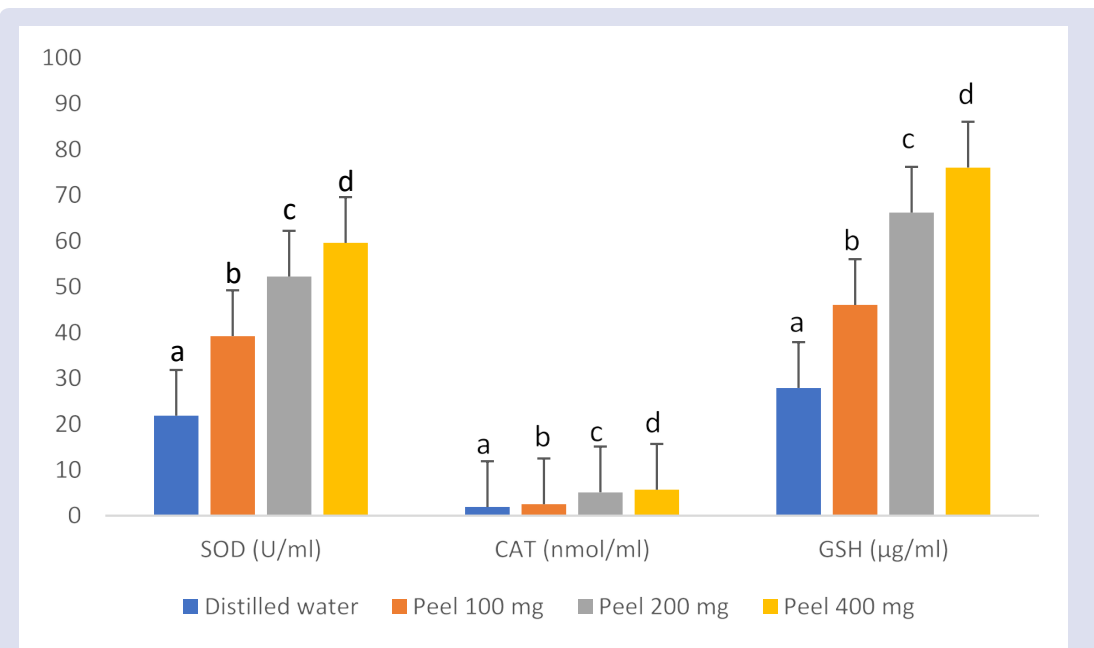

Figure 1: Comparison of superoxide dismutase, catalase, and glutathione of rat serum of control and treatment group. Bars with the same letters are not significantly different $(p<0.05)$.

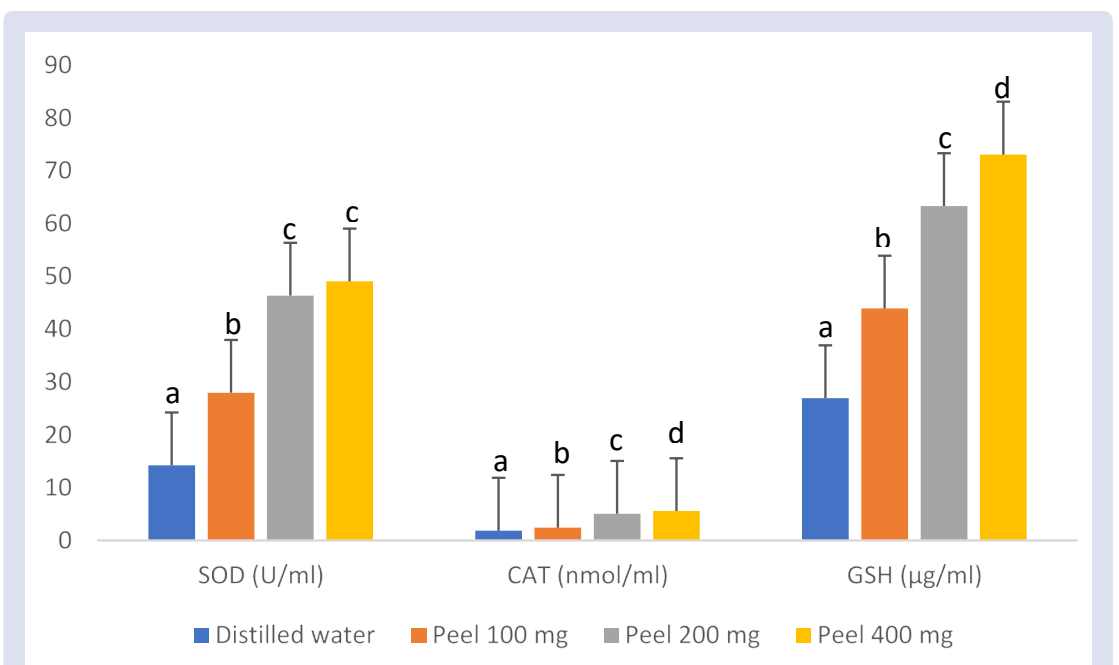

Figure 2: Comparison of superoxide dismutase, catalase, and glutathione of rat seminal plasma of control and treatment group. Bars with the same letters are not significantly different $(p<0.05)$.

Table 2: Superoxide dismuatse, catalase, and glutathione of type 2 diabetic rats seminal plasma on control and treatment group of Aloe vera peel extract.

\begin{tabular}{cccc}
\hline Group & $\begin{array}{c}\text { Superoxide dismutase (SOD) } \\
(\mathrm{U} / \mathrm{ml})\end{array}$ & $\begin{array}{c}\text { Catalase (CAT) (nmol/ } \\
\mathrm{ml})\end{array}$ & $\begin{array}{c}\text { Gluthatione (GSH) } \\
(\mu \mathrm{g} / \mathrm{ml})\end{array}$ \\
\hline $\mathrm{DM}+$ Distilled water & $14.22 \pm 7.09$ & $1.83 \pm 0.15$ & $26.91 \pm 2.96$ \\
$\mathrm{DM}+100 \mathrm{mg} / \mathrm{kg} /$ day & $27.94 \pm 6.93^{* \#}$ & $2.40 \pm 0.09^{* \#}$ & $43.89 \pm 4.09^{* \#}$ \\
$\mathrm{DM}+200 \mathrm{mg} / \mathrm{kg} /$ day & $46.32 \pm 5.64^{* *}$ & $5.04 \pm 0.09^{*}$ & $63.28 \pm 3.85^{* *}$ \\
$\mathrm{DM}+400 \mathrm{mg} / \mathrm{kg} /$ day & $49.02 \pm 6.79^{*}$ & $5.56 \pm 0.19^{* \#}$ & $73.02 \pm 2.33^{* *}$ \\
\hline
\end{tabular}

Data is presented as mean \pm SD. ${ }^{*} p<0.05$ compared to control, ${ }^{*} p<0.05$ between treatments

\section{DISCUSSION}

The level of blood glucose was found to be higher than the normal level. It indicates that there was oxidative stress by the elevation of free radicals and the mechanism of antioxidants alleviation. The results showed that serum SOD, CAT, and GSH levels in the diabetic group were significantly the lowest (Table 1, Figure 1 ). This result is the same as the results of the study of the Abo-Youssef $e t$ al. ${ }^{25}$, which stated that the group of diabetic rats induced by streptozotocin had decreased levels of SOD and GSH. The administration of Aloe vera skin extract at a dose of 100,200, and $400 \mathrm{mg} / \mathrm{kg}$ in diabetic rats could significantly increase serum SOD, CAT, and GSH. This result is supported by a study that was resulting in the levels of the antioxidant enzymes (SOD and GSH) increase, and the malondialdehyde (MDA) levels decrease with the administration of aqueous extract of Aloe vera doses at 150 and 300 $\mathrm{mg} / \mathrm{kg}^{26}$

The presence of free radicals can be reduced by involving endogenous and exogenous antioxidants. Food is the best source of various exogenous antioxidants. ${ }^{27}$ For example, vegetables and fruits are rich in vitamins (E, C) and polyphenol compounds, which are included as important antioxidants. ${ }^{28}$ In this case, Aloe vera peel contains organic and bioactive compounds that have great potential as antioxidants such as flavonoids, ascorbate acid, $\beta$-carotene, and $\alpha$-tocopherol. ${ }^{29}$ 
Aloe vera is one of the popular plants with its feature of active substances. Many previous studies used Aloe vera gel as antidiabetic agent $^{30,31}$ and to accelerate spermatogenesis. ${ }^{32,33}$ In this research, Aloe vera peel was proved that it has several constituents better than the gel part. Peel extract with ethanol solvent has free radical scavenger activity $39.7 \%$ greater than $14.2 \% .^{34}$ Antioxidant activity with 2,2-Azio-bis(3ethylbenzthiazoline-6-sulphonic acid) ABTS method at $10.4 \pm 0.5 \mathrm{mg} /$ $\mathrm{ml}$, total phenol $7.99 \pm 0.26 \mathrm{mg}$ gallic acid equivalent $(\mathrm{GAE}) / \mathrm{g}, 9.17 \pm$ $0.19 \mathrm{mg}$ quercetin equivalent $(\mathrm{QE}) / \mathrm{g}$ flavonoids were also higher than gel extracts. ${ }^{13}$

Antioxidant enzymes in seminal plasma also increased significantly in the group that received Aloe vera peel extract compared to the diabetes group (Table 2, Figure 2). Antioxidants in seminal plasma play an important role in protecting sperm because of the limitations of intracellular antioxidants. ${ }^{35}$ Seminal plasma has a rich source of antioxidants such as SOD, GSH, catalase, vitamin C, and vitamin E as a defense mechanism to protect sperm from oxidative stress. ${ }^{36}$

Enzymatic antioxidants are natural antioxidants to neutralize excess free radicals and to prevent cell damage. The SOD enzyme is the earliest defense against free radicals in all cells and converts $\mathrm{O}_{2}^{-}$to $\mathrm{H}_{2} \mathrm{O}_{2} \cdot{ }^{37}$ Glutathione peroxidase plays the role of its catalyst by reducing hydrogen peroxide and organic peroxide including phospholipid peroxide $^{38,39}$, whereas catalase breaks down hydrogen peroxide into oxygen and water. ${ }^{9}$

Aloe vera is one of the recognized medicinal plants in diabetes management and is beneficially protective acting as free radical scavengers and other antioxidant properties in diabetic patients. ${ }^{31}$ Aloe vera has antioxidant potential through mechanisms to inhibit the free radical formation and increase cellular thiol status. ${ }^{25}$ Presence of various antioxidants such as flavonoids can act directly to scavenge for reactive oxygen metabolites. ${ }^{26}$ Phenolic compounds and flavonoids contribute by donating hydrogen atoms. ${ }^{40}$ In addition, they also inhibit enzymes and elements involved in the formation of free radicals, reduce hydrogen peroxide, and produce highly reactive hydroxyl radicals. ${ }^{41}$ These antioxidant components can directly look for reactive oxidants, protect membranes lipids from lipid peroxidation which can ultimately reduce the total or partial clinical abnormality of diabetes. ${ }^{42}$

\section{CONCLUSION}

Aloe vera peel extract has a potency of reducing the oxidative in the diabetic rat by increasing the serum and seminal plasma antioxidant levels. Data from the study showed that administration of a peel extract dose of $400 \mathrm{mg} / \mathrm{kg}$ was able to provide the highest levels for SOD, CAT, and GSH.

\section{ACKNOWLEDGMENTS}

his research was supported by the Government of the Republic of Indonesia through the Directorate General of Higher Education (BPPS) and Semarang State University (UNNES) Year 2014-2018.

\section{CONFLICTS OF INTEREST}

All authors declare that there is no conflict of interest in this research content and its components of the process (sample, preparation, research, and publication).

\section{REFERENCES}

1. Awasthi A, Parween N, Singh VK, Anwar A, Prasad B, Kumar J. Diabetes: symptoms, cause and potential natural therapeutic methods. Adv Diabetes Metab. 2016;4(1):10-23

2. World Health Organization. Global Report on Diabetes: World Health Organization 2016: 6, Avenue Appia, 1211 Geneva 27, Switzerland.
3. Shaw JE, Sicree RA, Zimmet PZ. Global Estimates of the Prevalence of Diabetes for 2010 and 2030. Diabetes Res Clin Pract. 2010;87(1):4-14.

4. Maria-Luisa Lazo-de-la-Vega-Monroy, Cristina Fernández-Mejía. Oxidative stress in diabetes mellitus and the role of vitamins with antioxidant actions : Chapter 9 Intech Inc 2013. http://dx.doi.org/10.5772/51788

5. Chikezie PC, Ojiako OA, Ogbuji OC. Oxidative stress in diabetes mellitus Integr Obes Diabetes. 2015;1(3):71-9.

6. Ullah A, Khan A, Khan I. Diabetes mellitus and oxidative stress-A concise Saudi Pharm J. 2015

7. Matough FA, Budin SB, Hamid ZA, Alwahaibi N, Mohamed J. The role of oxidative stress and antioxidants in diabetic complications. Sultan Qaboos Univ Med J. 2012;12(1):5-18

8. Zatalia SR, Sanusi $H$. The role of antioxidants in the pathophysiology, complications, and management of diabetes mellitus. Acta Medica Indonesiana. 2013;45(2):141-7.

9. Kumar S. Free radicals and antioxidants: Human and food system. Adv Appl Sci Res. $2011 ; 2(1): 129-35$.

10. Manjunath K, Subash K, Tadvi N, Manikanta M, Rao U. Effect of Aloe vera leaf extract on blood glucose levels in alloxan induced diabetic rats. Natl J Physio Pharm Pharmacol. 2016;6(5):471-4.

11. Matheka DM, Alkizim FO. Complementary and alternative medicine for type 2 diabetes mellitus: Role of medicinal herbs. J Diabetes Endocrinol. 2012;3(4):4456.

12. Akinmoladun AC, Farombi EO, Oguntibeju OO. Antidiabetic botanicals and their potential benefits in the management of diabetes mellitus. AntioxidantAntidiabetic Agents and Human Health: InTech 2014.

13. Vidic D, Tarić E, Alagić J, Maksimović M. Determination of total phenolic content and antioxidant activity of ethanol extracts from aloe spp. Bull Chem Technol Bosnia Herzegovina. 2014;42:5-10

14. López A, de Tangil MS, Vega-Orellana O, Ramírez AS, Rico M. Phenolic constituents, antioxidant and preliminary antimycoplasmic activities of leaf skin and flowers of Aloe vera (L.) Burm. F.(Syn. A. Barbadensis Mill.) from the Canary Islands (Spain). Molecules. 2013;18(5):4942-54.

15. Narsih, Agato. Evaluation of bioactive compounds of aloe vera extract using subcritical water method. BTAIJ. 2016:12(3):113-20.

16. Ka HK, Min KH, Sun YH, Bo YM, Sook S, Jin HB, Yong Ho Park. Antimicrobial and immunomodulatory effects of Aloe vera peel extract. Journal of Medicinal Plants Research. 2011:5(22):5384-92.

17. Chaudhary A, Kumar N. Antimicrobial activity of zinc oxide nanoparticles synthesized from Aloe vera peel extract. SN Applied Sciences. 2019;1:136.

18. Chun-hui L, Chang-hai W, Zhi-liang X, Yi W. Isolation, chemical characterization and antioxidant activities of two polysaccharides from the gel and the skin of Aloe barbadensis Miller irrigated with sea water. Process Biochemistry. 2007;42(6):961-70

19. Christijanti W, Marianti A, Isnaeni W. Aloe vera extract reduces 8-oxo-2'deoxyguanosine levels and improves total antioxidant in streptozotocin-induced diabetic rats. Universa Medicina. 2017:36:34-41.

20. Ghasemi A, Khalifi S, Jedi S. Streptozotocin-nicotinamide-induced rat model of type 2 diabetes. Acta Physiol Hung. 2014;101(4):408-20.

21. Ghalehkandi, JG. Garlic (Allium Sativum) juice protects from semen oxidative stress in male rats exposed to chromium chloride. Animal Reproduction. 2014;11(4):526-32.

22. Tavilani H, Goodarzi MT, Vaisi-raygani A, Salimi S, Hassanzadeh T. Activity of antioxidant enzymes in seminal plasma and their relationship with lipid peroxidation of spermatozoa. International Braz J Urol. 2008; 34(4):485-91.

23. Shamsi M, Venkatesh S, Kumar R, Gupta N, Malhotra N, Singh N, et al Antioxidant levels in blood and seminal plasma and their impact on sperm parameters in infertile men. Indian J Biochem Biophys. 2010;47:38-43.

24. Shete S, Hulke SM, Thakare A, Patil P. Correlation of sperm function test with antioxidant levels in seminal plasma. Natl J Physiol Pharm Pharmacol. 2012;2(2):159-66

25. Abo-Youssef AMH, Messiha BAS. Beneficial effects of aloe vera in treatment of diabetes: Comparative in vivo and in vitro studies. Bull Fac Pharm Cairo Univ. 2013;51(1):7-11.

26. Mohapatra S, Pradhan S, Rath B, Tripathy S. Antioxidant properties of aloe vera in streptozotocin induced diabetic rats. Int J Pharm Bio Sci. 2013;4(3):187-91.

27. Dong-Ping $X, Y a L$, Xiao $M$, Tong $Z$, Yue $Z$, Jie Z. Natural antioxidants in foods and medicinal plants: Extraction, assessment and resources. Int. J Mol Sci. 2017;18:96. 
28. Bajaj S, Khan A. Antioxidants and diabetes. Indian J Endocrinol Metab. 2012;16(2):S267-71

29. Kumar S, Yadav J. Ethnobotanical and pharmacological properties of Aloe vera: A review. J Med Plants Res. 2014:8(48):1387-98.

30. Enas AKM. Antidiabetic, antihypercholestermic and antioxidative effect of aloe vera gel extract in alloxan induced diabetic rats. Aust J Basic Appl Sci. 2011;5(11):1321-7.

31. Ramachandraiahgari, Y, Madhavi R, Somesula SR, Adi PJ, Mannur IS, Enamala $\mathrm{M}$, et al. Protective role of ethanolic extract of aloe vera antioxidant properties on liver and kidney of streptozotocin-induced diabetic rats. Dig J Nanomater Biostructures. 2012:7(1):175-84.

32. Shahraki A, Mojahed AS, Afshar-Goli J. The effects of hydroalcoholic extract of aloe vera gel on spermatogenesis of adult male rats. Int J Biosci. 2014;5:15865.

33. Estakhr J, Javdan N. Spermatogenic activity of aloe vera in adult male rats. Pharmacologyonline. 2011;2:886-9.

34. Liu P, Chen D, Shi J. Chemical constituents, biological activity and agricultural cultivation of aloe vera-a review. Asian J Chem. 2013;25(12):6477-85.
35. Palani AF. Effect of serum antioxidant levels on sperm function in infertile male. Middle East Fertility Society Journal. 2018;(23):19-22.

36. Sheikh N, Amiri I, Najafi R, Goodarzi MT. The correlation between total antioxidant capacity and nitric oxide concentration in seminal plasma with sperm DNA damage. African Journal of Biotechnology. 2010; 9(35):5739-45.

37. Maria-Luisa LVM, Fernández-Mejía C. Oxidative stress in diabetes mellitus and the role of vitamins with antioxidant actions. 2013.

38. Adewoyin M, Ibrahim M, Roszaman, Md Isa ML, Alewi NAM, Rafa AAA, et al. Male infertility: the effect of natural antioxidants and phytocompounds on seminal oxidative stress. Diseases. 2017:5(9):1-26.

39. Amrit KB, Bilaspuri GS. Impacts of oxidative stress and antioxidants on semen functions. Veterinary Medicine International. 2011;1-7.

40. Ozsoy N, Candoken E, Akev N. Implications for degenerative disorders: antioxidative activity, total phenols, flavonoids, ascorbic acid, $\beta$-carotene and $\beta$-tocopherol in aloe vera. Oxidative Med Cell Longev. 2009;2(2):99-106.

41. Kumar S, Pandey AK. Chemistry and biological activities of flavonoids: An Overview. Sci World J. 2013:1-16.

42. Tiwari SC, Husain N. Biological activities and role of flavonoids in human health-A. Indian J Sci Res. 2017:12(2):193-6.

\section{GRAPHICAL ABSTRACT}

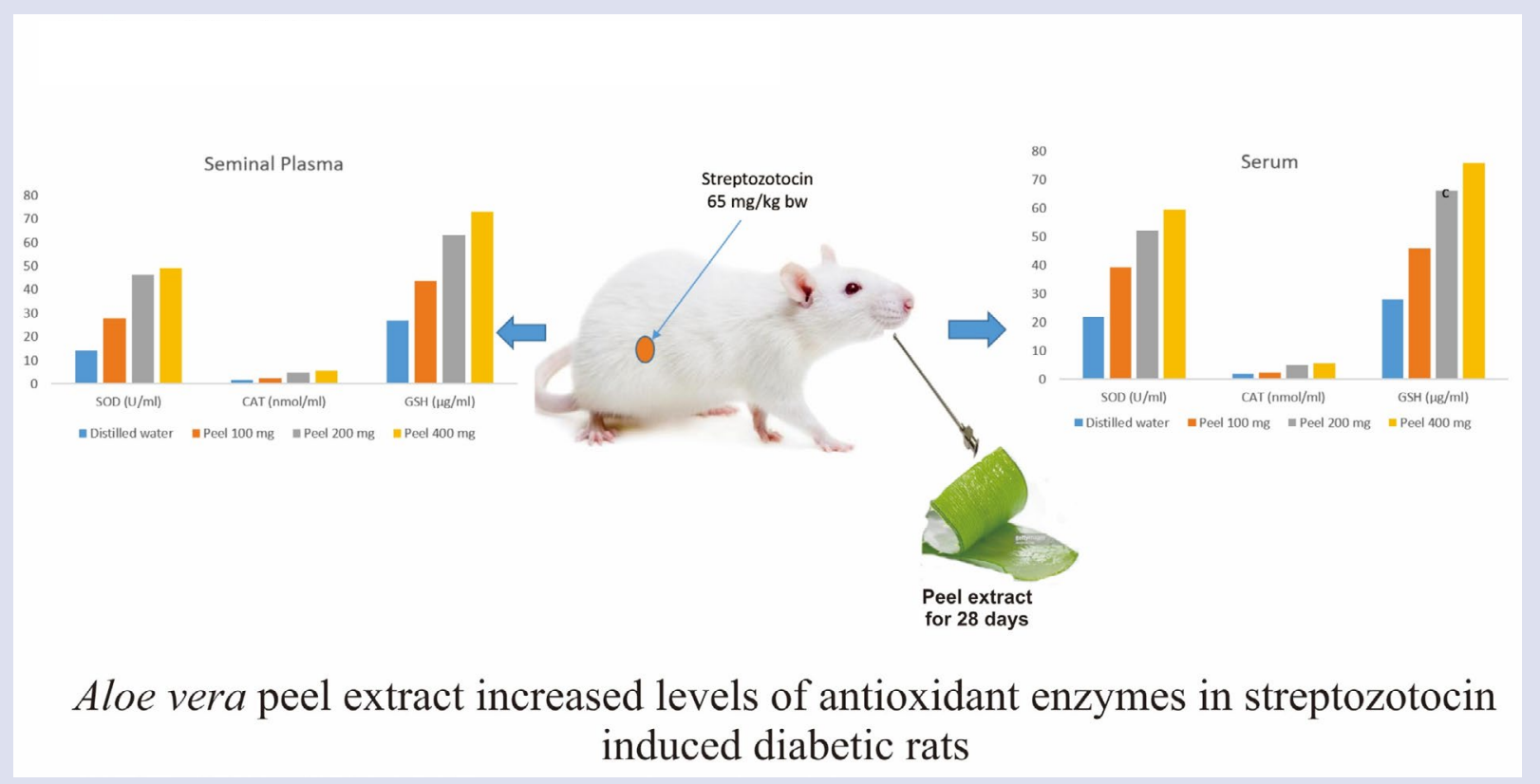

\section{ABOUT AUTHORS}

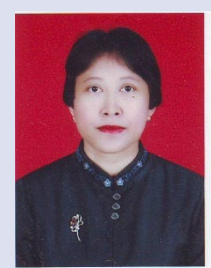

Wulan Christijanti since 1996 worked as a lecturer in Animal Physiology, Department of Biology, Faculty of Mathematics and Natural Sciences, Semarang State University. She is currently completing a doctoral program in the Doctoral Program in Medical / Health Sciences, Faculty of Medicine, Diponegoro University. Her research interest is the use of medicinal plants for the reproduction of male animals.

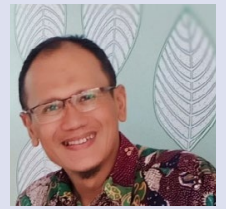

Dr. Achmad Zulfa is an Andrology specialist who received his PhD in 2014 from Erasmus Universiteit Rotterdam. 


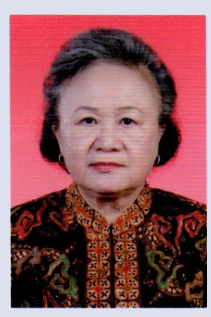

Prof. Lisyani Suromo was inaugurated as a Professor in 2007 as a lecturer in Clinical Pathology at the Faculty of Medicine Diponegoro University.

Cite this article: Christijanti W, Juniarto AZ, Suromo LB. Aloe Vera Peel Extract Administration Increased Antioxidant Enzyme Levels of Serum and Seminal Plasma in Type 2 Diabetic Rats. Pharmacog J. 2019;11(5):962-7. 